\title{
PENGARUH UMUR DAUN TEH DAN WAKTU OKSIDASI ENZIMATIS TERHADAP KANDUNGAN TOTAL FLAVONOID PADA TEH HITAM (Camellia sinesis)
}

\section{EFFECT OF TEA LEAVES AGE AND ENZIMATIC OXIDATION FOR TOTAL FLAVONOID CONTENTS IN BLACK TEA (Camellia sinesis)}

\author{
Jennifer Larisa Liem ${ }^{1}$, Maria Marina Herawati ${ }^{1 凶}$ \\ Prodi Agroteknologi, Fakultas Pertanian dan Bisnis, Universitas Kristen Satya Wacana \\ ${ }^{\bowtie}$ Komunikasi Penulis, email: maria.marina@uksw.edu \\ DOI:http://dx.doi.org/10.23960/jtep-l.v10i1.41-48 \\ Naskah ini diterima pada 15 Januari 2021; revisi pada 3 Februari 2021; \\ disetujui untuk dipublikasikan pada 2 Maret 2021
}

\begin{abstract}
Flavonoid compound is an important compound of tea products. However, the flavonoid level content in black tea is lowest than other teas. This is due to the processing of black tea which has an enzymatic oxidation stage and the tea age leaves when picking. Young tea leaves contain higher total flavonoids than old tea leaves. With an average level of total flavonoids, the young tea leaves is $27.76 \%$ qe $w / w$, while for the old tea leaves $18.61 \%$ qe $w / w$. However, the enzymatic oxidation time treatment did not affect the total flavonoids because the process only affected the quality of black tea steeping, on it's colour, aroma, and taste.
\end{abstract}

Keywords: age of tea leaves, black tea, enzymatic oxidation, total flavonoids

\begin{abstract}
ABSTRAK
Senyawa flavonoid merupakan senyawa penting dalam produk teh. Namun seringkali kandungan flavonoid dalam teh hitam rendah dibandingkan teh lainya. Hal ini dikarenakan proses pengolahan teh hitam yang terdapat tahap oksidasi enzimatis dan umur daun teh saat pemetikan. Daun teh muda memiliki kandungan total flavonoid yang lebih tinggi dibandingkan daun teh tua. Dengan kadar rata-rata total flavonoid daun teh muda yaitu $27,76 \%$ qe w/w, sedangkan untuk daun teh tua $18,61 \%$ qe w/w. Namun untuk perlakuan waktu oksidasi enzimatis tidak mempengaruhi total flavonoid dikarenakan proses tersebut hanya mempengaruhi kualitas seduhan teh hitam pada warna, aroma dan rasa.
\end{abstract}

Kata kunci: oksidasi enzimatis, teh hitam, total flavonoid, umur daun teh

\section{PENDAHULUAN}

Teh merupakan salah satu komoditas pertanian yang memiliki beberapa manfaat yang baik untuk kesehatan. Manfaat mengkonsumsi teh yaitu dapat menjaga kesehatan mulut dan gigi, melindungi kesehatan jantung dan penceranaan, selain itu dapat berfungsi sebagai zat antioksidan. Salah satu senyawa utama yang terkandung dalam teh dan memiliki manfaat dalam bidang kesehatan yaitu flavonoid. Flavonoid merupakan senyawa hasil metabolit sekunder yang dapat ditemukan pada tanaman hijau dan makanan (Wang et. al, 2016). Kandungan flavonoid pada teh dipengaruhi oleh beberapa faktor yaitu, umur daun, metode pemetikan teh, varietas teh, musim tanam, dan proses pengolahan (Turkemen et. al, 2009). Beberapa faktor yang akan dikaji yaitu umur daun teh dan teknik pengolahan teh.

Umur daun teh saat pemetikan mempengaruhi kandungan flavonoid pada teh, daun teh muda memiliki kandungan flavonoid lebih tinggi dibandingkan daun teh tua menurut penelitian yang dilakukan oleh Lin et. al (1996) kandungan flavonoid dalam bentuk total katekin pada daun teh muda yaitu $5,86 \%$ sedangkan pada daun teh 
tua yaitu 2,15\%. Selain itu menurut penelitian Chan et. al (2007), kandungan total polifenol (mg GAE/100g) pada daun teh muda lebih tinggi dibandingkan daun teh tua. Kriteria secara fisik untuk menentukan daun teh muda yaitu memiliki warna daun light green dan dalam 1 petikan terdiri dari 3 sampai 5 daun terhitung dari daun teratas. Sedangkan untuk daun teh tua memiliki kriteria berwarna dark green dan dalam 1 petikan terdiri dari 6 sampai 8 daun (Izzree et al, 2013).

Teknik pengolahan teh digolongkan menjadi 4 yaitu, teh tanpa fermentasi yaitu teh putih dan teh hijau, teh semi fermentasi yaitu teh olong dan teh fermentasi yaitu teh hitam. Teh hitam merupakan jenis teh yang pada proses pengolahannya mengalami fermentasi atau oksidasi enzimatis dan sering mengalami penurunan kadar flavonoid pada prosesnya (Rohdiana, 2015). Penurunan kandungan flavonoid pada teh hitam dikarenakan terjadinya proses oksidasi enzimatis yang akan mengubah senyawa flavonoid dalam bentuk katekin dan dirubah menjadi senyawa theaflavin dan thearubigin. Kelebihan dari 2 senyawa tersebut dapat menigkatkan cita rasa khas yang dihasilkan oleh teh hitam (Towaha, 2013). Proses oksidasi enzimatis dipengaruhi oleh suhu, waktu dan kelembaban udara. Menurut Obanda et. al (2001), suhu yang dikehendaki yaitu 20! dengan waktu 60 menit dan kelembaban udara diatas 90\% untuk menghasilkan senyawa theaflavin theaflavin stabil dan kualitas teh hitam yang bagus.. Selain itu menurut penelitian Asil et. al (2012), juga mengatakan bahwa waktu oksidasi enzimatis 60 menit dengan suhu 25! menghasilkan senyawa theaflavin stabil dan kualitas teh hitam yang bagus. Maka dari itu untuk memperoleh kandungan flavonoid yang tertinggi pada teh hitam perlu dilakukan penelitian mengenai umur daun teh dan penentuan waktu oksidasi enzimatis yang optimal diproses pengolahanya.

\section{BAHAN DAN METODE}

Penelitian ini dilaksanakan pada bulan September sampai November 2020. Penelitian ini dilakukan pada 3 tempat yaitu di , Unit Perkebunan Tambi, PT. Perkebunan Teh Tambi, Wonosobo, Jawa Tengah, dilanjutkan di
Laboratorium Fakultas Fisika Sains Matematika dan Fakultas Pertanian dan Bisnis, Universitas Kristen Satya Wacana, Salatiga. Bahan utama yang digunakan pada penelitian ini yaitu, daun teh varietas TRI 2025 yang ditanam pada ketinggian 1260-1845 mdpl, blok pemandangan, Unit Perkebunan Tambi, PT. Perkebunan Teh Tambi, Wonosobo. Kriteria secara fisik untuk menentukan daun teh muda segar yaitu dalam 1 petikan terdiri dari 3 sampai 5 daun terhitung dari daun teratas. Sedangkan untuk daun teh tua segar memiliki kriteria dalam 1 petikan terdiri dari daun ke 6 sampai 8 daun tidak terhitung dari pucuk. Daun muda dan daun tua berasal dari 1 tanaman yang sama dan hanya pucuk pecco yang digunakan untuk daun muda. Bahan kimia yang digunakan untuk analisis penelitian yaitu kuarsetin, etanol $60 \%, \mathrm{NaNO}_{3} 5 \%$ (natrium nitrat), $\mathrm{AlCl}_{3}$ 10\% (aluminium klorida), kertas saring, akuades, tissue, air. Sedangkan alat yang digunakan yaitu Whitering Through, OTR (On Top Roller), Mistycool, Thermometer, Hyrdrometer, keranjang, nampah, timbangan analitik, MC (Moisture content), Drier, ayakan, gunting, trolley, spektrofotometer UV-VIS T60 PG Instrumens England, mortar, pestle, grinder, labu ukur $100 \mathrm{ml}$, gelas beaker, ultrasonikator, Vortex Mixer, pipet volum, pilius, tabung reaksi dan rak tabung reaksi.

\subsection{Tahapan Penelitian}

Rancangan percobaan yang akan digunakan adalah RAKF (Rancangan Acak Kelompok Faktorial) dengan 2 faktor yang digunakan sebagai perlakuan yaitu umur daun teh dan waktu oksidasi enzimatis. U1 (umur daun teh muda), U2 (umur daun teh tua), W1 (waktu oksidasi enzimatis 60 menit), W2 (waktu oksidasi enzimatis 90 menit) dan W3 (waktu oksidasi enzimatis 120 menit). Data yang diperoleh dianalisis menggunakan analisis sidik ragam (ANOVA) dan apabila ada pengaruh maka dilanjutkan dengan menggunakan uji BNJ (Tukey) 5\%.

\subsection{Proses Pembuatan Teh Hitam}

Tahap pelayuan dilakukan dengan membeberkan daun teh pada Whitering Through, dan diletakan pada suhu $20-25^{\circ} \mathrm{C}$, lalu kelembaban udara yaitu 75-80\%. Proses pelayuan dilakukan selama 1520 jam dan dilakukan pembalikan sebanyak $1 \mathrm{x}$ agar proses pelayuan merata.Tahap penggilingan 
dilakukan secara konvensional. Daun teh digiling menggunakan OTR (On Top Roller) selama 45 menit. Lalu dilanjutkan dengan penggilingan secara manual menggunakan tangan yang beralaskan tampah. Proses penggilingan dilakukan pada suhu $20-25^{\circ} \mathrm{C}$ dengan kelembaban udara diatas $90 \%$. Tahap oksidasi enzimatis telah terjadi saat teh telah mengalami penggilingan, maka setelah proses penggilingan teh dibeberkan pada tampah dan dibiarkan sesuai waktu perlakuan (60 menit, 90 menit dan 120 menit).Tahap pengeringan dilakukan menggunakan Drier dan ayakan. Penggunaan ayakan dilakukan agar proses pengeringan merata. Suhu yang digunakan yaitu $60^{\circ} \mathrm{C}$ selama 30 menit dan dilakukan pembalikan setiap 10 menit. Teh yang telah mengalami pengeringan akan berwarna hitam dan mengeluarkan aroma teh.

\subsection{Parameter Pengujian}

\subsubsection{Pengujian Total Flavonoid Metode Spektrofotometri}

Pengujian flavonoid dilakukan pada sample daun teh segar dan teh hitam setelah dikeringkan. Terdapat 2 tahap yang dilakukan yaitu pembuatan ekstraksi sampel dan pengujian flavonoid sampel. Dalam tahap ekstraksi sample perlu ditentukan bahan pelarut (air, methanol dan etanol), waktu ekstraksi $(15,30$ dan 60 menit), suhu ekstraksi $\left(25^{\circ} \mathrm{C}, 40^{\circ} \mathrm{C}\right.$, dan $\left.60^{\circ} \mathrm{C}\right)$ dan metode ekstraksi (maerasi, perkolasi dan ultrasonikasi). Penentuan ini dilakukan untuk mendeteksi flavonoid yang optimal dengan parameter diatas. Tahap ekstraksi dilakukan dengan menimbang 1 gram sample daun segar teh dan teh hitam, lalu ditambahkan dengan 25 $\mathrm{ml}$ etanol $60 \% \mathrm{v} / \mathrm{v}$. Ekstraksi dilakukan selama 15 menit dengan suhu 40! dan menggunakan alat ultrasonikator. Lalu larutan ekstrak disaring dan filtratnya ditampung, sedangkan untuk residunya diekstrak kembali dengan $25 \mathrm{ml}$ etanol $60 \% \mathrm{v} / \mathrm{v}$. Tahap ekstraksi diulang sebanyak $3 \mathrm{x}$ dan hasil filtrat ditampung menjadi satu dalam labu ukur $100 \mathrm{ml}$. Pelarut etanol 60\% v/v ditambahkan pada filtrat hingga garis batas tera. Larutan ekstrak yang diperoleh berkonsentrasi $10 \mathrm{mg} /$ ml. Tahap selanjutnya adalah pengujian flavonoid sample dengan spektrofotometeri. 1 $\mathrm{ml}$ sample yang sudah diekstraksi ditambah dengan $4 \mathrm{ml}$ akuades dihomogenkan dengan vortex mixer. $0,3 \mathrm{ml} \mathrm{NaNO}_{3}$ 0,5\% ditambahkan dan dihomogenkan kembali dengan vortex mixer, lalu didiamkan selama 5 menit. Ditambahkan kembali $0,3 \mathrm{ml} \mathrm{AgCl}_{3} 10 \%$ dan dihomogenkan kembali dengan vortex mixer, lalu didiamkan selama 5 menit Tambahkan aquades hingga larutan menjadi $0 \mathrm{ml}$ dan dihomogenkan kembali dengan vortex mixer. Larutan didiamkan selama 15 menit pada suhu ruang. Pengukuran absorbansi flavonoid dilakukan pada panjang gelombang $510 \mathrm{~nm}$. Nilai absorbansi yang didapatkan dikonversi untuk mendapatkan nilai total flavonoid berdasarkan kurva kalibarasi quercetin. Untuk kurva kalibrasi dibuat berdasarkan seri konsentrasi quercetin $20,40,60,80 \mathrm{dan} 100 \mu \mathrm{g} / \mathrm{ml}$.

\section{HASIL DAN PEMBAHASAN}

Terdapat 4 faktor yang mempengaruhi kandungan flavonoid pada teh yaitu, umur daun teh, metode pemetikan, varietas teh dan proses pengolahan. Parameter daun teh muda disini merupakan hasil petikan $\mathrm{P}+5$ sedangkan daun teh tua merupakan hasil petikan daun ke enam hingga kedelapan tidak terhitung dari pucuk peko. Pengambilan sample daun teh segar untuk dianalisis awal dilakukan secara random sampling pada block budidaya yang sama dan ketinggian tanaman yang sama. Hasil sampling tersebut diambil 2 tanaman untuk tiap perlakuannya untuk dianalisis awal total flavonoid.

Berdasarkan Tabel 1 menunjukan bawah total flavonoid pada daun teh muda segar lebih tinggi dibandingkan daun teh tua segar, hal ini dikarenakan daun teh muda terdapat pucuk peko. Pucuk peko adalah daun muda yang masih aktif bertumbuh dikarenakan tersusun oleh jaringan meristem. Selain itu terjadi proses source (sumber) dan sink (lubuk) dimana daun tua sebagai source menyalurkan hasil metabolisme ke sink yaitu daun muda. Jaringan meristem yang terdapat pada pucuk peko membutuhkan hasil fotosintat untuk proses pertumbuhan (Snyder and Carlson, 1983). Selain itu menurut Saslowsky and Brenda (2001), zona pemanjangan dan tudung akar Arabidopsis merupakan daerah penimbunan flavonoid dan enzim yang memproduksi flavonoid yaitu 
kalkone sintase dan kalkone isomerase. Maka dari itu kandungan flavonoid lebih tinggi pada daun muda dibandingkan daun tua.Hasil fotosintat yang disuplai ke daun muda selain digunakan untuk proses pertumbuhan, terjadi juga proses pembentukan metabolit sekunder salah satunya yaitu flavonoid. Proses pembetukan flavonoid menggunakan jalur skhikimat, proses ini terjadi pada vakuola daun.

Hasil dari fotosintesis dalam bentuk karbon diproses dalam metabolisme karbon, 2 hasil dari proses metabolisme karbon dalam bentuk Erythorose-4-phosphate dan Phosphoenol piruvat menjadi prekusor dalam pembentukan metabolit sekunder (Taiz and Zeiger, 2015). Maka dari itu hasil kandungan total flavonoid pada perlakuan umur daun muda lebih tinggi dibandingkan daun tua. Menurut hasil analisis yang dilakukan oleh PPTK Gambung (2006) dalam Anjarsari (2016), kandungan katekin dalam bentuk \% berat kering pucuk peko relative tinggi yaitu $26,5 \%$ dibandingkan daun pertama, kedua, ketiga dan tangkai. Tahapan yang menjadi titik utama pengolahan teh hitam yaitu proses oksidasi enzimatis. Berikut total flavonoid teh hitam dengan perlakuan umur daun teh dan waktu oksidasi enzimatis.

Data pada Table 2 untuk perlakuan umur daun teh berpengaruh nyata terhadap kandungan flavonoid pada produk teh hitam. Sedangkan untuk perlakuan waktu oksidasi enzimatis tidak berpengaruh nyata terhadap kandungan flavonoid. Hal ini dikarenakan proses oksidasi enzimatis hanya proses pembentukan kualitas

Tabel 1. Hasil Pengujian Total Flavonoid pada Daun Teh Muda dan Daun Teh Tua dalam Bentuk Daun Segar

\begin{tabular}{cccc}
\hline \multirow{2}{*}{ Sample } & \multicolumn{2}{c}{$\begin{array}{c}\text { Total Flavonoid } \\
(\% \mathbf{q e} \text { w/w) }\end{array}$} & \multirow{2}{*}{$\begin{array}{c}\text { Rata-rata total flavonoid } \\
\text { (\% qe w/w) }\end{array}$} \\
\cline { 2 - 3 } & $\mathbf{I}$ & II & 30,63 \\
Daun teh muda & 30,45 & 30,82 & 28,71 \\
Daun teh tua & 29,29 & 28,13 & \\
\hline
\end{tabular}

Keterangan: \% w/w $=1 \mathrm{~g}$ flavonoid $/ 100 \mathrm{~g}$ sample

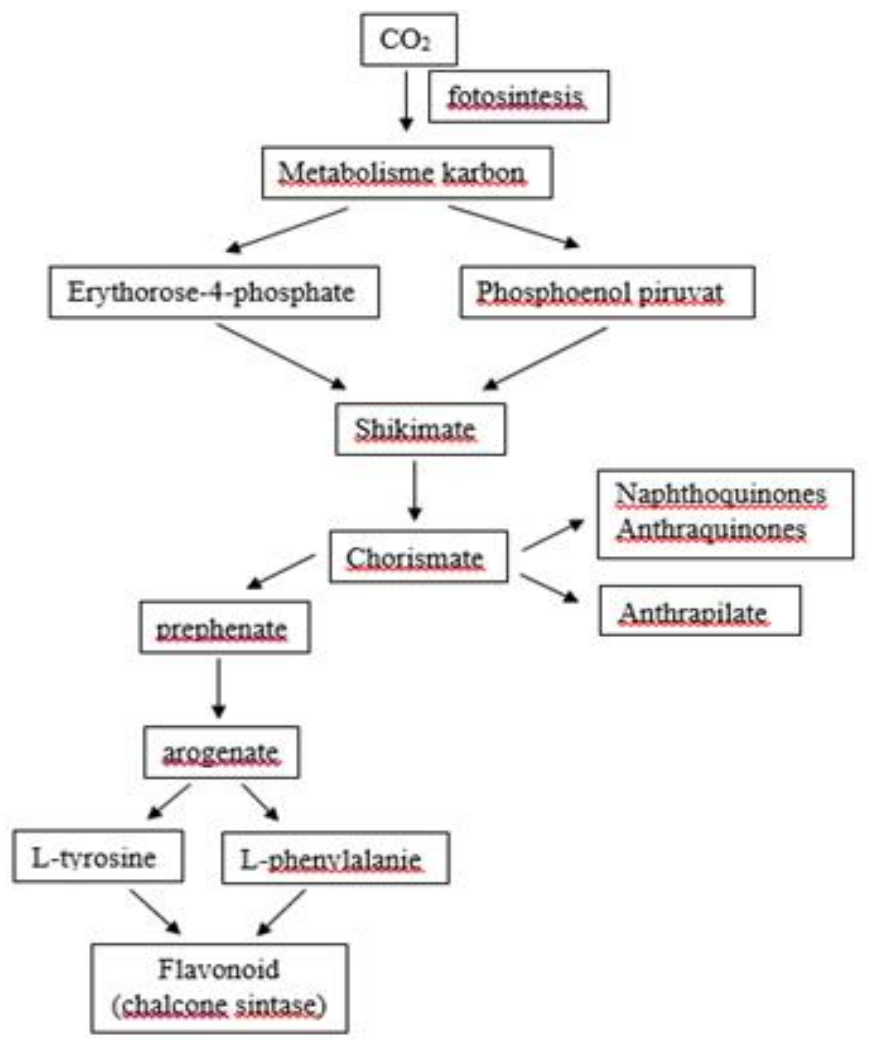

Gambar 1. Proses Pembentukan Flavonoid (Taiz and Zeiger, 2015 dan Wink, 1999) 
dari teh hitam saja. Oksidasi enzimatis adalah proses perubah senyawa flavonoid dalam bentuk katekin menjadi theaflavins dan thearubigins dibantu dengan enzim polyphenol oxidase.Proses oksidasi enzimatis ini berawal dari proses keluarnya carian pada sel daun saat proses penggulungan, cairan tersebut senyawa flavonoid yang berada pada vakuola daun berfungsi sebagai katalisator yang akan diubah menjadi theaflavin dengan bantuan enzimpolyphenol oxidaseyang tersimpan dalam sitoplasma dan oksigen. Akibat dari perubahan theaflavin menjadi thearubigin secara kondensasi menghasilkan warna cairan sel menjadi gelap menjadi hitam (Werkhoven, 1974). Gambar 2 menunjukan alur pembentukan theaflavin dan thearubigin pada teh hitam.
Maka dari itu waktu oksidasi enzimatis tidak berpengaruh nyata terhadap kandungan flavonoid dikarenakan proses tersebut hanya menghasilkan kualitas warna seduhan teh hitam. Jika dibandingkan dengan teh hijau, kandungan flavonoid teh hijau lebih tinggi dibandingkan dengan teh hitam. Hal ini dikarenakan pada teh hijau hanya terjadi setengah oksidasi enzimatis yaitu saat proses penggulungan, akibatnya warna seduhan yang dihasilkan oleh teh hijau cenderung warna alami yaitu hijau karena tidak terjadi proses perubahan katekin menjadi menjadi theaflavins dan thearubigins.

Table 3 terlihat penurunan atau degradasi total flavonoid pada daun teh tua lebih tinggi yaitu sebanyak $35,17 \%$ qe w/w dibandingkan dengan

Tabel 2. Hasil Pengujian Total Flavonoid Teh Hitam

\begin{tabular}{ccccc}
\hline Pelakuan & W1 & W2 & W3 & Rerata Umur \\
\hline U1 & 26,55 & 27,63 & 29,10 & $27,76(\mathrm{~A})$ \\
U2 & 19,87 & 18,86 & 17,11 & $18,61(\mathrm{~B})$ \\
\hline Rerata waktu & $23,21(\mathrm{~A})$ & $23,24(\mathrm{~A})$ & $23,11(\mathrm{~A})$ & $(-)$
\end{tabular}

Keterangan: angka yang ditandai dengan huruf berbeda menyatakan berbeda nyata menurut Uji Tukey pada taraf $5 \%$. Tanda (-) tidak menunjukan interaksi antara perlakuan umur daun teh dengan waktu oksidasi enzimatis.

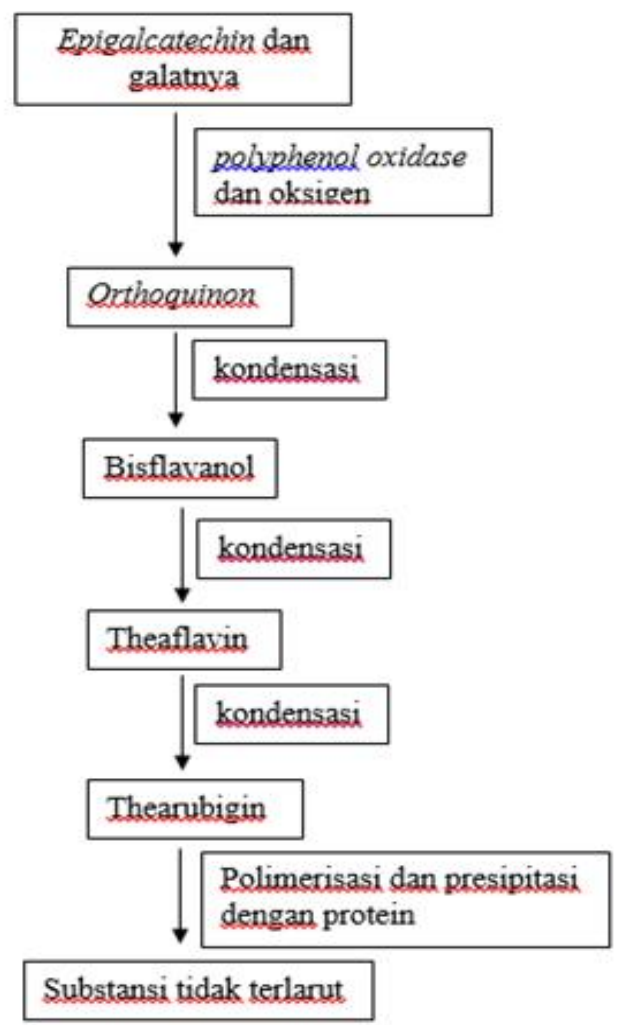

Gambar 2. Proses Pembentukan Theaflavin dan Thearubigin (Rohdiana, 1999) 
Tabel 3. Penurunan Total Flavonoid pada Teh Hitam

\begin{tabular}{|c|c|c|c|}
\hline \multirow[b]{2}{*}{ Umur Daun Teh } & \multicolumn{2}{|c|}{ Total Flavonoid (\% qe w/w) } & \multirow{2}{*}{$\begin{array}{c}\text { Degradasi Total } \\
\text { Flavonoid } \\
(\% \text { qe w/w) }\end{array}$} \\
\hline & $\begin{array}{c}\text { Sebelum } \\
\text { Pengolahan }\end{array}$ & $\begin{array}{c}\text { Sesudah } \\
\text { Pengolahan }\end{array}$ & \\
\hline Muda & 30,63 & 27,76 & 9,36 \\
\hline Tua & 28,71 & 18,61 & 35,17 \\
\hline
\end{tabular}

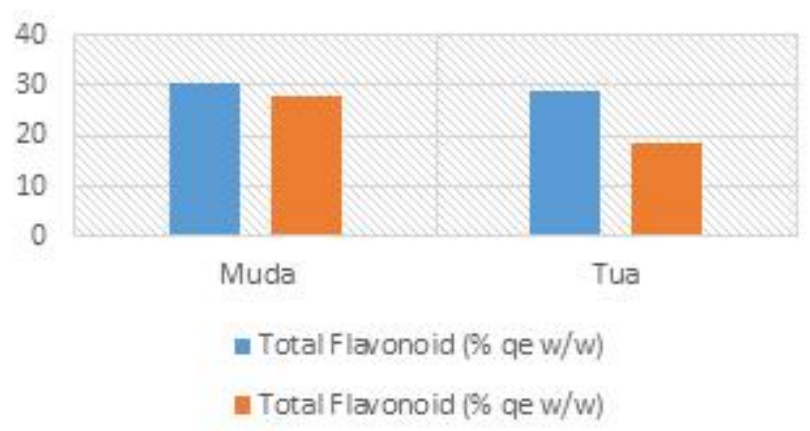

Gambar 3. Penurunan Total Flavonoid Daun Teh Muda, Daun Teh Tua Sebelum dan Sesudah Pengolahan Teh Hitam

daun teh muda yaitu sebanyak $9,6 \%$ qe w/w. Pada proses pengolahan teh, pelayuan merupakan titik kritis dalam menentukan kualitas teh yang akan dihasilkan. Proses pelayuan terjadi proses penurunan kadar air hingga daun menjadi lemas pada suhu $20-25^{\circ} \mathrm{C}$ selama 14-18 jam (Emdadi, et al, 2013; Sato, et al, 2007; Rohdiana, 2015). Akibat terjadi kadar air, pada proses pelayuan teh terdapat perubahan fisik dan perubahan kimia daun teh. Perubahan fisik yaitu daun teh menjadi lemas namun tidak kering, sedangkan perubahan kimia daun teh adalah proses penurunan kandungan kimia pada teh salah satunya total flavonoid.Flavonoid pada daun teh terletak pada vakuloa sedangkan enzim polifenol oksidase terletak pada sitoplasma. Flavonoid dan enzim polifenol oksidase dibatasi dengan membran tonoplas (Anjarsari, 2016). Disaat terjadi proses penurunan kadar air pada daun teh, terjadi juga proses permeabilitas pada membran sel daun yang meningkat dan enzim polifenol oksidase dengan flavonoid tercampur. Berpotensi terjadinya oksidase enzimatis namun tidak optimal dibandingkan dengan proses penggilingan.

Pada penelitian ini secara penampakan fisik daun teh tua tidak sesegar daun teh muda, maka dari itu saat proses pelayuan daun teh tua relative lebih cepat lemas dan cenderung kering saat proses pelayuan berakhir yang dilakukan pada suhu $20-25,5^{\circ} \mathrm{C}$ selama 18 jam. Akibat dari itu penurunan total flavonoid dalam daun teh tua lebih tinggi dibandingkan daun teh muda.

\section{KESIMPULAN}

Kandungan total flavonoid pada teh hitam dipengaruhi umur daun teh segar hal ini dikarenakan umur daun teh muda memiliki kandungan total flavonoid yang relative lebih tinggi dibandingkan daun tua. Kandungan total flavonoid pada umur daun teh muda segar yaitu $30,63 \%$ qe w/wdan untuk daun teh tua segar yaitu $28.71 \%$ qe w/w. Namun untuk perlakuan waktu oksidasi enzimatis tidak berpengaruh terhadap kandungan flavonoid dalam teh hitam dikarenakan proses oksidasi enzimatis hanya mempengaruhi kualitas seduhan teh hitam.

\section{DAFTAR PUSTAKA}

Angraiyati, D dan Faizah, H. 2017. Lama Pengeringan Pada Pembuatan Teh Herbal Daun Pandan Wangi (Pandanus Amarylifolius Roxb.,) Terhadap Aktivitas Antioksidan. JOM Faperta UR. 4(1): 1-12.

Asil, M.H., Babak, R., Reza, H. A. 2012. Optimal Fermentation Time and Temperature to 
Improve Biochemical Composition and Sensory Characteristics Of Black Tea. Australian Journal of Crop Science. 6(3): 550-558

Biju, J. Sulaiman, C. T. Satheesh, G and V R K Reddy. 2014. Total Phenolics and Flavonoids in Selected Medicinal Plants From Kerala. International Journal of Pharmacy and Pharmaceutical Sciences. 6(1): 406-408.

Chan, E. W. C., Y. Y. Lim., Y. L. Chew. 2007. Antioxidant Activity of Camellia Sinensis Leaves and Tea from a Lowland Plantation In Malaysia.Journal Food Chemistry.102: 1214-1222.

Emdadi, L., B. Nasernajad., S.T. Shokrgozar., M. Mehranian and F. Vahazadeh. 2009. Optimization of Withering Time and Fermentation Conditions During the Manufacture of Black Tea Using a Response Surface Methodology.Chemistry and Chemical Engineering. 16(1): 61-68.

Grotewold, E. 2006. The Science of Flavonoid. United States of America: Springer.

Izzreen, N., Q and Mohd, F., A., B. 2013. Phytochemicals and Antioxidant Properties of Different Parts of Camellia Sinensis Leaves From Sabah Tea Plantation In Sabah, Malaysia. International Food Research Journal. 20(1): 307-312.

Lin, Y., Juan, I., Chen, Y., Liang, Y., Lin, J.1996. Composition of Polyphenols In Fresh Tea Leaves and Associations of Their OxygenRadical-Absorbing Capacity With Antiproliferative Actions In Fibroblast Cells.J. Agric. Food Chem. 44: 1387-1394.

Obanda, et. al. 2001. Changes In The Chemical and Sensory Quality Parameters of Black Tea Due to Variations of Fermentation Time and Temperature.Food Chemistry. 75: 395-404.

PPTK Gambung. 2006 dalam Anjasari. 2016. Katekin Teh Indonesia: Prospek dan
Manfaatnya. Jurnal Kultivasi. 15(2): 99106.

Riyanto, Ph. D. 2014. Validasi \& Verifikasi Metoda Uji. Sesuai dengan ISO/IEC 17025. Laboratorium Pengujian dan Kalibrasi[Edisi 1 Cetakan 1].2014. Yogyakarta: Deepublish.

Rohdiana, D. 1999. Evaluasi Kandungan Theaglavin dan Thearubigin Pada Teh Kering Dalam Kemasan. JKTI. 9(1-2): 2932.

Saslowsky, David and Brenda Winkel-Shirley. 2001. Localization of Flavonoid Enzymes in Arabidopsis Roots. The Plant Journal. 27(1): 37-48.

Sato, D., Namiko, I., and Tomomi, K. 2007. HomeProcessing Black Tea and Green Tea (Camellia sinensis). Food Safety and Technology FST-26. Japan.

Snyder, F.W. and Carlson, G.E. 1983. Selecting for Partitioning of Photosynthetic Products In Crops. Advances in Agronomy. 37: 47 69.

Taiz, L and Zeiger, E. 2015. Plant Physiology 6 th Ed. Massachusetts: Sinauer Associates.

Towaha, J. 2013. Kandungan Senyawa Kimia Pada Daun Teh (Camellia sinensis). Warta Penelitian dan Pengembangan Tanaman Industri. 19(3): 12-16.

Turkmen, N., Ferda, S., Y. Sedat. V. 2009. Factor Affecting Polyphenol Contet and Composition on Fresh and Processed Tea Leaves. Review Paper Akademik Gida. 7(6): 29-40.

Wang, Qinghu., Jinmei, J., Nayintai, D., Narenchaoketu, H., Jingjing, H., Baiyinmuqier, B. 2016. Antilnûammatory Effects, Nuclear Magnetic Resonance Identiûcation and High Performance Liquid Chromatography Isolation of The Total Flavonoids From Artemisia Frigida. Journal Of Food and Drug Analysis. 24: 385-391. 
Werkhoven, J. 1974. Tea Processing. Amsterdam: Wink, M. 1999. Biochemistry of Plant Secondary Royal Tropical Institute. Metabolism. Annual Plant Reviews [Vol 2] Sheffield: Sheffield Academic Press. 